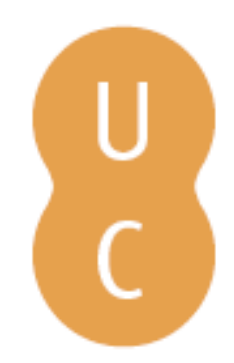

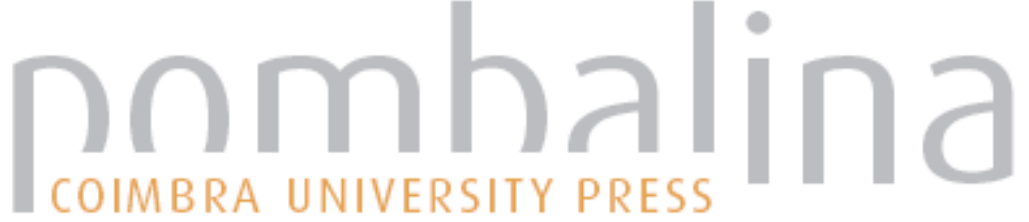

\section{Is there a critical fuel moisture content for flammability?}

\begin{tabular}{ll} 
Autor(es): & Terrah, S. M.; Sabi, F. Z.; Mosbah, O.; Dilem, A.; Hamamousse, N.; \\
& Sahila, A.; Harrouz, O.; Zekri, N.; Kaiss, A.; Clerc, J-P.; Rahli, O.; Giroud, \\
Publicado por: & Imprensa da Universidade de Coimbra \\
$\begin{array}{ll}\text { URL } \\
\text { persistente: }\end{array}$ & URI:http://hdl.handle.net/10316.2/44574 \\
DOI: & DOI:https://doi.org/10.14195/978-989-26-16-506_57 \\
Accessed : & 26-Apr-2023 12:50:28 \\
\hline
\end{tabular}

A navegação consulta e descarregamento dos títulos inseridos nas Bibliotecas Digitais UC Digitalis, UC Pombalina e UC Impactum, pressupõem a aceitação plena e sem reservas dos Termos e Condições de Uso destas Bibliotecas Digitais, disponíveis em https://digitalis.uc.pt/pt-pt/termos.

Conforme exposto nos referidos Termos e Condições de Uso, o descarregamento de títulos de acesso restrito requer uma licença válida de autorização devendo o utilizador aceder ao(s) documento(s) a partir de um endereço de IP da instituição detentora da supramencionada licença.

Ao utilizador é apenas permitido o descarregamento para uso pessoal, pelo que o emprego do(s) título(s) descarregado(s) para outro fim, designadamente comercial, carece de autorização do respetivo autor ou editor da obra.

Na medida em que todas as obras da UC Digitalis se encontram protegidas pelo Código do Direito de Autor e Direitos Conexos e demais legislação aplicável, toda a cópia, parcial ou total, deste documento, nos casos em que é legalmente admitida, deverá conter ou fazer-se acompanhar por este aviso.

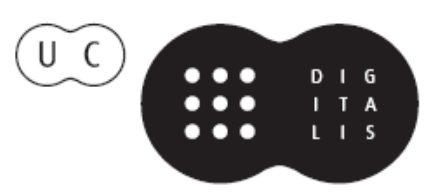




\section{ADVANCES IN}

\section{FOREST FIRE RESEARCH}

\section{8}

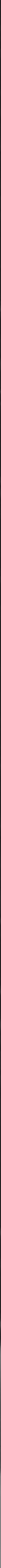




\title{
Is there a critical fuel moisture content for flammability?
}

\author{
S. M. Terrah ${ }^{1}$; F. Z. Sabi ${ }^{1}$; O. Mosbah ${ }^{1}$; A. Dilem ${ }^{1}$; N. Hamamousse ${ }^{1,2}$; A. Sahila ${ }^{1}$; O. Harrouz ${ }^{1}$;

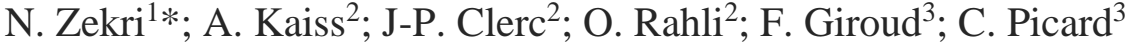 \\ ${ }^{1}$ Université des Sciences et de la Technologie d'Oran, LEPM BP 1505 El Mnaouer Oran, Algeria, \\ \{nzekri@yahoo.com*\} \\ ${ }^{2}$ Aix Marseille Université. CNRS, IUSTI UMR 7343, 13453 Marseille, France \\ ${ }^{3}$ CEREN, Domaine de Valabre, 13120 Gardanne, France
}

\section{Abstract}

The moisture threshold for ignition has attracted land managers and has been the main subject of discussion for several decades. The critical moisture of extinction is still a subject of extensive studies, and an endothermic/exothermic phase transition is expected to occur near the critical region. Ignition tests were realized for live pinus halepensis needles using a cone calorimeter. In order to ensure the live character of the fuel and avoid seasonal effects and changes in their chemical structure during ignition, the samples were picked the same day from the same tree, then partially dried using a microwave and a desiccator. By definition, phase transitions occur when a small variation of an external control parameter leads to a qualitative modification of the system. In order to determine whether the moisture content is the control parameter of the endothermic/exothermic phase transition or not, we had to verify the existence of a moisture content threshold for ignition by analysing the dependence of ignition time on moisture content. The experimental data have shown no critical moisture for the fuel ignition. We pointed out that the observed critical region corresponds to an ignition critical heat flux rather than a critical moisture.

Keywords: Critical moisture, flammability, pinus halepensis needles.

\section{Introduction}

Fuel moisture content is one of the most important variables affecting fire behaviour. It is known that moist fuels are relatively non-flammable, and even if the flammability occurs, the rate of combustion is reduced to less intense fires in contrast to the dry fuels that burn more fiercely (Pompe and Vines 1966, Van Wagner 1967, Trabaud 1976, Catchpole and Catchpole 1991). Jervis et al. (Jervis et al. 2015) showed that the most flammable samples are fresh dead and aged needles followed by dry dead and dry live needles. The least flammable are the fresh live needles. This confirms the importance of moisture content in the burning behaviour of pine needles, but the differences between live and dead samples cannot be explained solely in terms of moisture. It requires also the consideration of plant chemistry and sample drying. Live needles (green colour) are part of the foliage. Dead pine needles (red colour) are on the ground.

Not all studies have had success when correlating flammability measures with moisture content (Trabaud 1976, Fletcher 2007). Ignition fluctuations are caused by the dispersion of volatiles, moisture and the exposition of fuel particles in the sample. Recently, McAllister and Weise (McAllister and Weise 2017) pointed out that not only the moisture affects the fuel flammability, but also the chemical composition of volatiles. Live and dead fuels can have very different volatile components and then different ignition and combustion properties. The moisture threshold for ignition has been the main subject of discussion for several decades and has attracted land managers. A still unexplained empirical observation is the "moisture of extinction" (Cohen and Bradshaw, 1986; Rothermel, 1972; Weise et al., 2005). Wildland fires in dead fuels will not spread above some threshold of fuel moisture content, typically assumed to be between 10\% and 40\% (Rothermel, 1972). Actually, Trabaud 1976 has examined the effect of moisture content on the flammability and combustibility of various wildland

Advances in Forest Fire Research 2018 - Page 522 
dead fuels using an epiradiator at $620^{\circ} \mathrm{C}$. He proposed the following hyperbolic behaviour of the ignition time $\left(t_{i g n} \propto 1 /\left(h_{c}-h\right)\right)$. The moisture content $h$ is defined as:

$$
h=\left(m-m_{d r y}\right) / m
$$

with $m_{d r y}$ the dried mass and $m$ the mass of the moist sample. $h_{c}$ is the maximum moisture above which ignition cannot occur.

Near the critical moisture of ignition, an endothermic/exothermic phase transition is expected to occur. Phase transitions, as observed in various fields such as conductor/insulator (Stauffer 1992), liquid/gas (Blundell et al. 2006) and paramagnetic/ferromagnetic (Pokrovskii 1979), are characterized by a strong disorder near the threshold. They are also characterized by diverging or vanishing quantities following a universal power-law formula near the critical region (Stanley 1971, Yeomans 1992). In the case of ignition/non ignition phase transition, ignition time must diverge near the critical moisture as:

$$
t_{i g n} \sim\left(h_{c}-h\right)^{-\gamma}
$$

Where $h$ is the moisture content defined by (1), $h_{c}$ is the maximum moisture content allowing ignition estimated by Trabaud. Thus, it is defined as the critical moisture. The power-law formula (2) is characterized by a critical exponent $\gamma$ which distinguishes different phase transitions. The hyperbolic formula proposed by Trabaud is equivalent to (2) with a critical exponent $\gamma=1$, and the maximum moisture allowing ignition can be identified as the critical moisture content.

However, these tests were realized during several seasons or years, and the fuel was dried naturally. The fuel chemical composition changes from a season to another, leading to a variation in flammability and combustibility properties.

In the present work, ignition tests are realized for live pinus halepensis needles using a cone calorimeter. In order to ensure the live character of the fuel during ignition, the samples are picked the same day from the same tree, then partially dried to avoid seasonal effects. The ignition time dependence on moisture content (Eq. 2) is analysed to determine whether or not there is a critical moisture content for ignition.

\section{Experimental setup}

During the period from January to March 2018, pine needles (pinus halepensis) were picked from the same tree early in the morning (at $8.00 \mathrm{am}$ ). Immediately after the harvest, samples of live needles of 15 and 25 gr were prepared for the determination of the moisture content of the vegetation. For this purpose, two drying techniques were used; a SAMSUNG household microwave at 800 watts and an infrared radiation dryer (Kern type MLS 3C). The samples are completely dried in the microwave (25g for 3 minutes), and in the desiccator $\left(15 \mathrm{~g}\right.$ at $80{ }^{\circ} \mathrm{C}$ for 24 hours). The holding time of the samples in the microwave and the desiccator determines the dry mass $\left(m_{d r y}\right)$, the moisture content $h_{\max }$ of the fresh samples and the maximum drying time for the two devices. The preparation of the samples at various intermediate moistures is realized by varying sample holding times $t$ in the two drying devices so as to cover the entire range of moistures $(t \leq 24 h$ for the radiation dryer, and $t \leq 3 \mathrm{mn}$ for the microwave). Hence, the wet mass is obtained after the holding time $t(m=m(t))$, and the moisture content relative to this mass is defined by (1) with $h=h(t)$. Once dried, the samples are placed in a cylindrical mesh sample holder of $10 \mathrm{~cm}$ diameter. Then, these samples are exposed to a constant radiation heat flux provided by a cone calorimeter whose heat source is an electrical resistance of a power of $3000 \mathrm{~W}$. The experimental device is shown schematically in Fig.1. The incident heat flux at the top surface position of the sample $q^{\prime \prime}$ (which depends on the distance from the cone heater) is measured by a water cooled heat flux sensor of type Hukseflux SBG 01 working in the range $0-$ 
$200 \mathrm{~kW} / \mathrm{m}^{2}$ and its magnitude is fixed to $17 \mathrm{~kW} / \mathrm{m}^{2}$. This magnitude of the heat flux is far from the critical heat flux for pinus halepensis needles, which is about $10 \mathrm{~kW} / \mathrm{m}^{2}$ (Sabi et al. 2018). The ignition is controlled by a pilot flame located $1 \mathrm{~cm}$ above the sample surface (Torero 2016), and the ignition time is recorded. To take into account the heterogeneity of the fuel structure arrangement in the sample, each test is repeated three (3) times. All the measurements are made in the same day to guarantee that the tests are done on a live fuel with the same composition of organic flammable volatiles. All tests were conducted in a draft-free room with room temperatures and relative humidities in the ranges $13-19^{\circ} \mathrm{C}$, and $50-60 \%$, respectively.

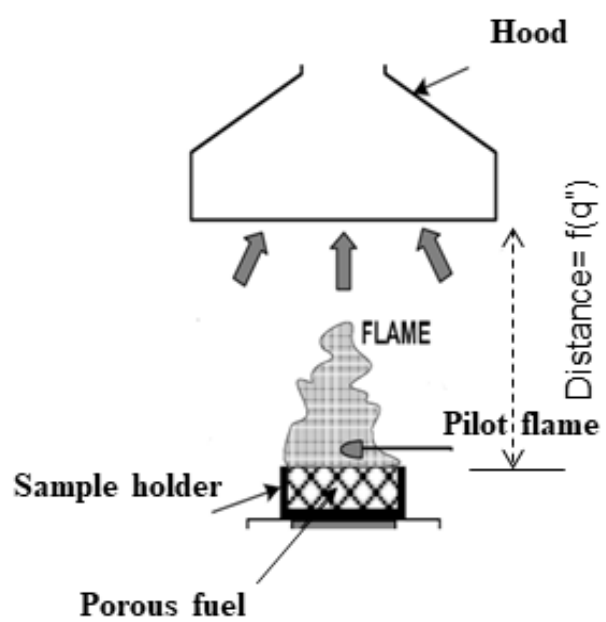

Figure 1 - A schematic representation of the experimental setup.

It is worth noticing that carrying out ignition tests on a constant mass of the sample after drying (e.g . 10g) may lead to significant errors on the ignition and combustion times. Indeed, once the sample has been dried (either partially or totally), its mass decreases, but the amount of volatile components responsible of ignition remains nearly constant in it. The drying techniques are assumed to evaporate mostly water. The release of volatile organic components (VOC) was found to increase as the temperature increases (Jervis and Rain 2015). Hence, it is expected that the MLS dryer at $80^{\circ} \mathrm{C}$ enhances the ignition time fluctuations contrary to the microwave device. Indeed, the microwave device emits radiations at a frequency of $2.45 \mathrm{GHz}$, which corresponds to the water characteristic dielectric frequency. Thus, it is mostly absorbed by the molecules of water leading to their evaporation. Then, it is expected that the release of VOC is significantly reduced with the microwave device.

If a constant part of the dried mass $\mathrm{m} \leq \mathrm{m}(\mathrm{t})$ is ignited, the remaining amount of volatiles decreases proportionally to $\mathrm{m} / \mathrm{m}(\mathrm{t})=1-\mathrm{h}$ from $(1)$, and ignition is thus influenced by the drying process. In order to guarantee the same quantity of volatiles in the sample for each test independently of the moisture content, it is necessary to burn all the dried mass.

\subsection{The ignition process}

When a solid material, initially at ambient temperature, is subject to an external source of energy, the temperature of the exposed surface starts to increase. This moment is defined as the onset of the ignition process $(t=0)$. A series of physical and chemical phenomena are initiated as the energy reaches the surface of the material. The sample is composed of fine fuel particles arranged randomly. This yields a porosity distribution with an average value defined as the ratio of solid fuel volume to the fuel bed volume. When exposed to a heat flux, the particles are heated and loose energy by conductive and convective mechanisms (Torero et al. 2016). Thus, a solid-liquid-gas transformation occurs inducing a flammable gas/oxygen mixture at a low flammability limit and ignition temperature (Drysdale 2011). High porosity renders the overall thermal conductivity of a solid quite low making the ignition easier to happen. Therefore, auto-ignition is very difficult to occur as the condition for the 
emitted gas/air mixture to reach the low flammability limit and, simultaneously, the surface temperature to reach ignition temperature has a finite probability to not be realized. By definition, in the presence of a pilot source (such as a small flame, a heated wire or an electric spark) in the reactive fuel/air mixture flow, we have a piloted (or forced) ignition. A pilot source is not meant to heat the solid to generate the fuel gases nor to enhance the mixing of the fuel gases with air, but to locally induce the combustion reaction which would propagate into the mixture.

As an event, ignition occurs at a certain pronounced instant in the history of the exposure. The time to ignition in a given situation depends on three broadly grouped factors: 1) the degradative thermal response of the solid to yield the combustible gases, 2) the mixing of these gases with the oxygen (generally the oxygen of the normal air), and 3) the induction of the temperature and composition-dependent rate of the combustion reaction to a sufficiently high level to be measurable and self-supporting (Kanury 2008). The same ignition process occurs for a moist sample exposed to a heat flux, but the water evaporation complicates it. In the case of a thick fuel bed, water evaporation decreases the surface temperature and ignition can be delayed.

\section{Results and discussions}

The effect of moisture content on the ignition time is shown in Figs. 2 for fuels dried by microwave and also by the desiccator (for the data of January, only $10 \mathrm{~g}$ of the dried sample were burned). The present data are also compared with those of Trabaud (1976) for pinus halepensis. As discussed above, the MLS dryer induces a larger fluctuations of the ignition time compared to the microwave device, because of the influence of VOC release during the drying process. It is also obvious from Fig.2a that burning the full sample dried by microwave reduces signficantly the fluctuations of ignition time. Compared to the results of Trabaud where burning could not occur above a moisture of $20 \%$, the present samples were ignited even for moisture contents above $50 \%$. The heat flux received by the fuel from the epiradiator used by Trabaud might be much smaller than $17 \mathrm{KW} / \mathrm{m}^{2}$ (provided by our cone calorimeter). The heat flux provided by the epiradiator could be smaller than the critical flux for ignition, which is around $5.5 \mathrm{~kW} / \mathrm{m}^{2}$ for pinus halepensis needles (see Sabi et al. 2018). In order to answer this question, we assume the critical moisture as an exothermic/endothermic phase transition. Therefore, near the critical moisture, ignition time diverges according to (2). In Fig.2b, the same data of Fig.2a are presented in the double logarithmic plot as a function of $h_{c}-h$. The value of the critical moisture $h_{c}$ is estimated so as to obtain a linear fit with the best correlation coefficient $\left(\mathrm{R}^{2}\right)$.

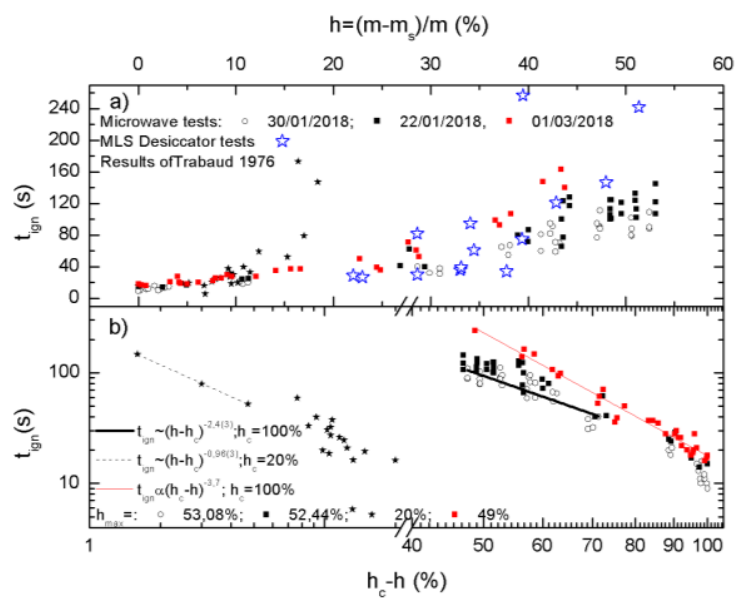

Figure 2 - a) tign vs. h for various moistures obtained by microwave and desiccator, and Trabaud's results. b) same as Fig.2a with log-log plot.

The best linear fit in Fig.2b is obtained for $h_{c}$ around $100 \%$. This means that the endothermic/exothermic phase transition occurs when the fuel mass vanishes, and only water 
evaporation occurs. Clearly, there is no critical moisture for ignition. The non flammability in the results of Trabaud at a moisture of about $\mathbf{2 0 \%}$ means that the samples were exposed to a heat flux around the critical flux for this moisture content. In addition, the power-law (2) is fitted in this figure only for three points located near the critical moisture. For each of these moisture contents, only one ignition test was successful, whereas far from the moisture threshold, in all tests, the ignition process occured. Therefore, a probabilistic behaviour occurs near the moisture threshold, which should correspond to the critical heat flux (Sabi et al. 2018).

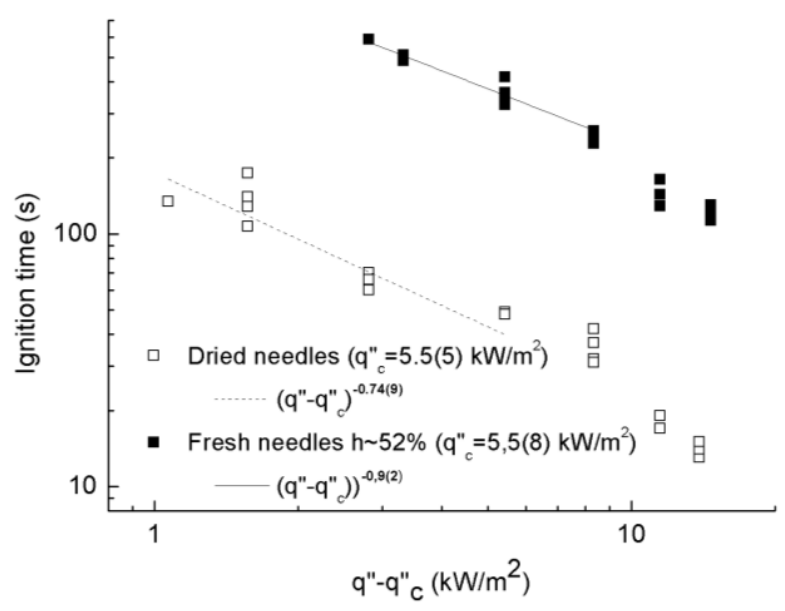

Figure 3 - A double logarithmic plot of $t_{i g n} v s . q^{\prime \prime}-q^{\prime \prime}$ for fresh and dry pinus halepensis needles.

In order to check whether the ignition threshold is due to the heat flux or the moisture content, a set of tests with fresh and dry samples were realized for different values of the incident heat flux $\boldsymbol{q}^{\prime \prime}$. The critical heat flux for ignition defines the endothermic /exothermic transition (Sabi et al. 2018). The ignition time behaves near this transition as:

$$
t_{\text {ign }} \alpha\left(q "-q{ }^{\prime}\right)^{-\alpha}
$$

The power exponent in Fig. 3 seems to be around -0.8 independently of the moisture content and of the fuel nature (see Sabi et al. 2018), indicating a universal phase transition (Stanley 1971). Therefore, for any moisture content, there exists a sufficiently large heat flux allowing the fuel ignition.

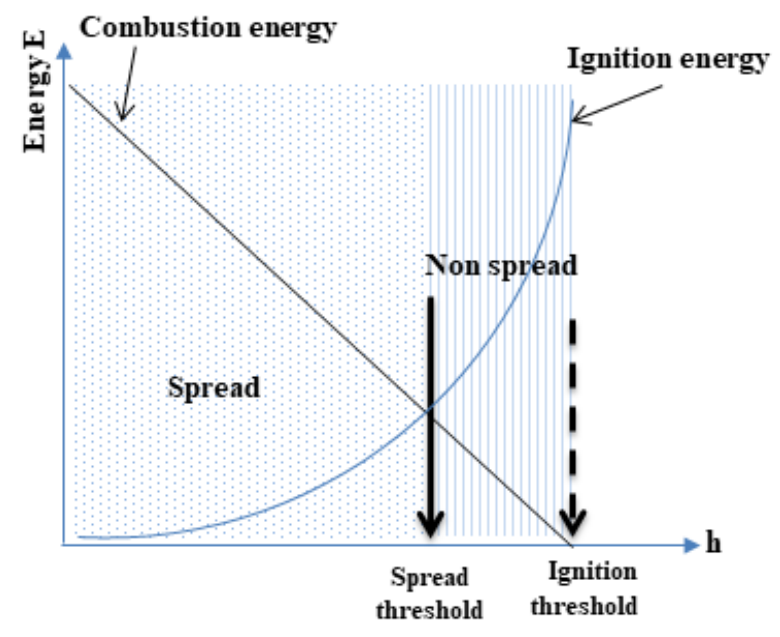

Figure 4 - A schematic representation of the ignition and combustion energies vs. the moisture content h. Ignition and spreading thresholds are clearly shown.

Advances in Forest Fire Research 2018 - Page 526 
In wildland fires, fire residence time is finite (30-40s for fine fuels) in contrast to that provided by the cone calorimeter where the radiant heat flux is maintained until the fuel ignition. Therefore, the comparison between the combustion and ignition energies leads to either spread or no spread of fire. The critical moisture for fire spread can be defined as the moisture content for which combustion and ignition energies coincide, as shown in Fig.4. This spread condition is not realistic since only a proportion of the released combustion energy is received by the fuel. This makes a much smaller critical moisture for spread. Therefore, the existence of a critical moisture is expected for wildfire spread, although it is considered as a retardant. Indeed, the moisture can make the ignition time as large as it becomes greater than the residence time of the flames to which the fuel is exposed. This corresponds to a dynamical threshold of spread as found by Zekri et al. (Zekri et al. 2005) using a Small World Network model. This model was validated by historical and experimental fires (Adou et al. 2010). Obviously, fire do not spread during winter, when the fuel is moist. Hence, the effect of moisture on the spreading phase transition is necessary to investigate both experimentally (experimental burning in fields) and theoretically (using physical models involving water desorption and evaporation).

\section{Conclusion}

The moisture threshold for ignition is examined by using the endothermic/exothermic phase transition analysis of the ignition time dependence on moisture content. Ignition tests of live pinus halepensis needles were realized using a cone calorimeter. The fuel samples were partially dried using a microwave and a desiccator. In order to avoid seasonal effects and changes in their chemical structure, live fuels were picked the same day from the same tree. The power law fit of the ignition phase transition showed no critical moisture for the fuel ignition. The critical region for ignition observed by Trabaud in 1976 corresponds to the ignition critical heat flux for the corresponsing moisture content. Further studies for other fuels wil be realized to confirm this result.

\section{References}

Adou JK, Billaud Y, Brou DA, Clerc JP, Consalvi JL, Fuentes A, Kaiss A, Nmira F, Porterie B, Zekri L., Zekri N (2010), Simulating wildfire patterns using a small-world network model, Ecol.Modelling, 221, 1463-1471.

Blundell SJ and Blundell KM (2006), 'Concepts in Thermal Physics', (Oxford University Press, Oxford).

Catchpole EA, Catchpole WR (1991), Modelling Moisture Damping for Fire Spread in a Mixture of Live and Dead Fuels, International Journal of Wildland Fire 1, 101-106.

Chandler C, Cheney P, Thomas P, Trabaud L, Williams D (1983) 'Fire in forestry. Vol. I. Forest fire behaviour and effects' (John Wiley \& Sons: New York)

Cohen J and Bradshaw B (1986) Fire behavior modeling - A decision tool. In 'Proceedings Prescribed Burning in the Midwest: State of the Art' (Ed. A. L. Koonce), University of Wisconsin at Stevens Point, Stevens Point, WI, 1-5.

Drysdale D (2011), An Introduction to Fire Dynamics, (3rd Ed. John Wiley and

Sons, Chichester)

Fletcher TH, Picket BM, Smith SG, Spittle GS, Woodhouse MM, Haake E, Weise DR (2007), Effect of moisture on ignition behaviour of moist California chaparral and Utah leaves, Combust. Sci. Technol., 179, 1183-1203.

Jervis FX and Rein G (2015), Experimental study on the burning behaviour of pinus halepensis needles using small-scale fire calorimetry of live, aged and dead samples, Fire Mater. 40, 385-395 
Kanury AM (2008), Flaming Ignition of Solid Fuels. In 'The SFPE handbook of fire protection engineering'. (3rd Eds Society of Fire Protection Engineers). (National Fire Protection Association), section 2 Chap 11.

McAllister S and Weise DR (2017) Effect of season on ignition of live wildland fuels using the forced ignition and flame spread test apparatus. Comb Sc. \& Technol., 185, 231-247

Pokrovskii V. (1979) Properties of ordered, continuously degenerate systems, Adv.Phys. 28, 595-656

Pompe A, Vines RG (1966), The influence of moisture on the combustion of leaves, Australian forestry, 30, 231-241.

Rothermel RC (1972), A mathematical model for predicting fire spread in wildland fuels. USDA For. Serv. Res. Pap. INT-115. 40.

Sabi FZ, Zekri N (2018), Ignition/non ignition phase transition (This conference)

Stanley HE (1971) 'Introduction to phase transitions and critical phenomena' (Clarendon Press Oxford)

Stauffer D, Aharony A (1992), 'Introduction to Percolation Theory', (Taylor and Francis, London).

Trabaud L (1976), Inflammabilité et combustibilité des principales espèces des garrigues de la région méditerranéenne, Oecol. Plant. 11, 117-136

Torero J (2016), Flaming ignition of solid fuels. In 'SFPE Handbook of fire protection engineering' . (Ed MJ Hurley) (Springer: Heidelberg) pp 633-661.

Van Wagner CE (1967), Seasonal variation in moisture content of eastern canadian tree foliage and the possible effect on crown fires, Canada Dept. Forestry, For.Res.Br.-1204 (Edmonton).

Weise DR, White RH, Beall FC, and Etlinger M (2005), Use of the cone calorimeter to detect seasonal differences in selected combustion characteristics of ornamental vegetation. Int. J.Wildland Fire, $14,321-338$.

Yeomans JM (1992) 'Statistical mechanics of phase transitions' (Clarendon Press Oxford)

Zekri N, Porterie B, Clerc J-P, Loraud J-C (2005) Propagation in a two-dimensional weighted local small-world network, Phys. Rev.E 71, 046121 